\title{
Chitinolytic enzymes of the rumen ciliate Eudiplodinium maggii
}

\author{
R. Miltko • G. Belzecki • T. Michalowski
}

Received: 9 December 2011 / Accepted: 4 January 2012 / Published online: 13 April 2012

(C) The Author(s) 2012. This article is published with open access at Springerlink.com

\begin{abstract}
The ability of rumen ciliates to digest chitin is clearly recognized. We investigated the chitinolytic system of the rumen ciliate Eudiplodinium maggii. The ciliates were grown in a selectively faunated sheep. They were isolated from the rumen and purified by sedimentation. A crude enzyme preparation was prepared following incubation of ciliates with antibiotics. This was done in order to reduce their contamination with intracellular bacteria. The activity of particular enzymes was examined by quantification of the products released from specific substrates. It was stated that the optimum conditions for the detected activities varied between 4.5 and $5.5 \mathrm{pH}$, and 45 and $55{ }^{\circ} \mathrm{C}$. $\beta$ - $N$-Acetylglucosaminidase was found as an enzyme of the highest activity $(4.2 \mu \mathrm{mol} / 1$ released product per $\mathrm{mg}$ protein per $\mathrm{h}$ ). The activities of endochitinase and exochitinase were almost two times lower than that of $\beta-N$-acetylglucosaminidase. Zymographic studies revealed the presence of two endochitinases, two exochitinases and two $\beta$ - $N$-acetylglucosaminidases in the examined preparation.
\end{abstract}

R. Miltko $(\bowtie) \cdot$ G. Belzecki $\cdot$ T. Michalowski

The Kielanowski Institute of Animal Physiology and Nutrition Polish Academy of Sciences,

Instytucka 3,

05-110 Jabłonna near Warsaw, Poland

e-mail: r.miltko@ifzz.pan.pl

\section{Introduction}

Rumen ophryoscolecid protozoa engulf readily the fungal zoospores which are rich in chitin (Williams and Coleman 1997; Lee et al. 2001). We already found that the ciliates Eudiplodinium maggii digest and ferment chitin (Miltko et al. 2010). However, no information is available on chitinolytic enzymes of this species of rumen protozoa. The objective of this study was to identify and characterize chitinolytic enzymes of this species of ciliates.

\section{Materials and methods}

The ciliates E. maggii were identified after Dogiel (1927). They were isolated from the natural rumen fauna of sheep. The ciliates were cultured under in vitro conditions according to Michalowski et al. (1991) and were then inoculated into the rumen of ciliates-free sheep (Michalowski et al. 1999). The ciliates living in the rumen of monofaunated sheep (see above) were used to perform the enzymic experiments. The samples of the fluid (about 11 ) were withdrawn from the rumen and the protozoa were isolated and purified by sedimentation (Michalowski 1990). The purified ciliates were incubated overnight with a mixture of antibiotics (chloramphenicol, streptomycin and ampicillin) each of 
which was supplied at the final concentration of $50 \mu \mathrm{g} / \mathrm{ml}$. The antibiotics were used in order to restrict the intracellular bacteria. After incubation, the ciliates were washed three times with warm $\left(40^{\circ} \mathrm{C}\right)$ caudatum type salt (Coleman et al. 1972). Finally, they were concentrated by the sedimentation method and stored at $-80{ }^{\circ} \mathrm{C}$. To obtain the enzyme preparation the frozen ciliates were thawed and homogenized in a glass homogenizer equipped with a Teflon pestle. The resulting homogenate was centrifuged $\left(22,000 \times \mathrm{g}, 30 \mathrm{~min}, 4{ }^{\circ} \mathrm{C}\right)$ and the supernatant was collected and used as a crude enzyme preparation. The activity of endochitinase was determined by quantification of reducing sugars released from carboxymethylchitin (Wirth and Wolf 1990) following its incubation with crude enzyme preparation. Reaction mixture consisted of $0.4 \mathrm{ml}$ substrate, $0.4 \mathrm{ml}$ enzyme preparation and $0.2 \mathrm{ml}$ $0.1 \mathrm{~mol} / 1$ citrate-phosphate buffer. The mixture was incubated for $1 \mathrm{~h}$ at $40{ }^{\circ} \mathrm{C}$ and the released products were measured spectrophotometrically according to Miller et al. (1960). The exochitinase and $\beta-N$ acetylglucosaminidase activities were determined by measurements of nitrophenyl released by crude enzyme preparation from 4-nitrophenyl- $N, N$-diacetyl-Dchitobioside and 4-nitrophenyl- $\beta-N$-acetylglucosaminide, respectively. Reaction mixture consisted of $100 \mu \mathrm{l}$ solution of $1 \mu \mathrm{mol} / 1$ substrate, $50 \mu \mathrm{l}$ enzyme preparation and $150 \mu 10.1 \mathrm{~mol} / \mathrm{l}$ citrate-phosphate buffer. It was incubated for $1 \mathrm{~h}$ at $40^{\circ} \mathrm{C}$ and the released product was quantified according to Yem and $\mathrm{Wu}$ (1976). Native polyacrylamide gel electrophoresis (PAGE) of crude enzyme preparation in combination with zymography technique was applied to identify the chitin degrading enzymes (Wirth and Wolf 1990). Carboxymethylchitin, 4-methylumbelliferyl- $\beta$-D- $N, N$-diacetylchitobioside and 4-methylumbelliferyl- $N$-acetyl- $\beta$-D-glucosaminide were added as the specific substrates to the separating gels to identify endochitinase, exochitinase and $\beta-N$-acetylglucosaminidase, respectively.

Table 1 Characterization of chitinolytic enzymes of Eudiplodinium maggii $^{\mathrm{a}}$

\begin{tabular}{llll}
\hline Chitinolytic activity & $\begin{array}{l}\mathrm{pH} \\
\text { optimum }\end{array}$ & $\begin{array}{l}\text { Temperature } \\
\text { optimum } \\
\left({ }^{\circ} \mathrm{C}\right)\end{array}$ & $\begin{array}{l}\text { Degradation rate } \\
(\mu \mathrm{mol} / \mathrm{l} \text { released } \\
\text { product per mg } \\
\text { protein per } \mathrm{h})\end{array}$ \\
\hline Endochitinase & 5.5 & $45-55$ & 1.7 \\
Exochitinase & $4.5-5.0$ & 45 & 2.0 \\
$\beta-N$-Acetylglucosaminidase & 4.5 & 55 & $4.2 *$ \\
\hline
\end{tabular}

${ }^{\mathrm{a}}$ Mean values $(n=3)$

$* p<0.05$
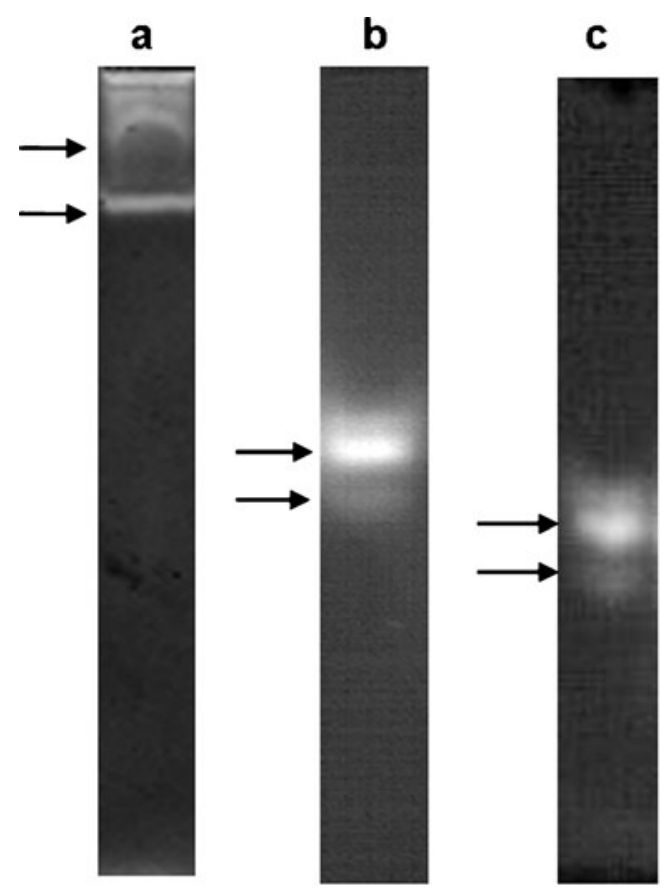

Fig. 1 Chitinolytic enzymes of the rumen ciliate Eudiplodinium maggii identified by the zymogram technique; protozaol proteins were separated by native PAGE. a Endochitinases, b Exochitinases, c $\beta$ - $N$-acetylglucosaminidases; arrows bands exhibiting chitinolytis activity

\section{Results and discussion}

We showed that E. maggii ciliates possess endochitinase, exochitinase and $\beta-N$-acetylglucosaminidase which were responsible for the breakdown of chitin. This finding supports the earlier results concerning of chitinolytic properties of Diploplastron affine (Belzecki et al. 2008). They showed also that the most active was $\beta-N$ acetylglucosaminidase. It was 12 times more active than the similar enzyme which was found in E. maggii by Williams et al. (1986). The endochitinase and exochitinase were similar in their activities $(p>0.05)$ which were about two times lower than $\beta$ - $N$-acetylglucosaminidase (Table 1).

In general, six protein bands exhibited the ability to degrade chitin or its derivatives (Fig. 1). Two of them were endochitinases, two were exochitinases, and two were $\beta-N$ acetylglucosaminidases.

Acknowledgements This study was supported by Grant No. N311 046134, from the Polish Ministry of Scientific Research and Information Technology. 
Open Access This article is distributed under the terms of the Creative Commons Attribution License which permits any use, distribution, and reproduction in any medium, provided the original author(s) and the source are credited.

\section{References}

Belzecki G, Miltko R, Michalowski T, Šimůnek J, Kopečný J (2008) Chitinolytic activity of sheep rumen ciliate Diploplastron affine. Folia Microbiol 53:201-203

Coleman GS, Davies JI, Cash MA (1972) The cultivation of rumen ciliates Epidinium ecaudatum caudatum and Polyplastron multivesiculatum in vitro. J Gen Microbiol 73:509-521

Dogiel VA (1927) Monographie der Familie Ophryoscolecidae. Arch Protistenk 59:1-288

Lee Ss, Ha JK, Cheng K-J (2001) The effects of sequential inoculation of mixed rumen protozoa on the degradation of orchard grass cell walls by anaerobic fungus Anaeromyces mucronatus. Can J Microbiol 47:754-760

Michalowski T (1990) The distribution of ciliates through the reticulorumen of sheep. Acta Protozool 29:213-222
Michalowski T, Harmeyer J, Belzecki G (1999) The importance of washing the omasum for successful defaunation of sheep. Anim Feed Sci 8:611-619

Michalowski T, Muszynski P, Landa I (1991) Factors influencing the growth of rumen ciliates Eudiplodinium maggii in vitro. Acta Protozool 25:419-426

Miller GL, Blum R, Glennon WE, Butron AL (1960) Measurement of carboxymethylcellulase activity. Anal Biochem 2:127-132

Miltko R, Belzecki G, Kwiatkowska E, Michalowski T (2010) The ability of the rumen protozoan Eudiplodinium maggii to utilize chitin. Folia Microbiol 55:349-351

Wirth SJ, Wolf GA (1990) Day-label substrates for the assay and detection of chitinase and lysozyme activity. J Microbiol Method 12:197-205

Williams AG, Coleman GS (1997) The rumen protozoa. In: Hobson PN, Stewart CS (eds) The rumen microbial ecosystem, 2nd edn. Blackie Academic and Professional, London, pp 73-120

Williams AG, Ellis AB, Coleman AG (1986) Subcellular distribution of polysaccharide depolymerase and glycoside enzymes in rumen ciliate protozoa. Curr Microbiol 13:139-147

Yem DW, Wu HC (1976) Purification and properties of $\beta-N$-acetyloglucosoamidase from Escherichia coli. J Bacteriol 12(5):324 331 